\title{
Using GIS and methods of digital cartography for analyzing battlefield engravings of $17^{\text {th }}$ century
}

\author{
Tomáš Janata and Růžena Zimová \\ Czech Technical University in Prague, Faculty of Civil Engineering, Dept. of Geomatics, \\ Thákurova 7, 16629 Prague 6, Czech Republic \\ tomas. janata@fsv.cvut.cz \\ zimova@fsv.cvut.cz
}

\begin{abstract}
Iconographic sources depicting Thirty Years' War battlefields in the Czech lands can be found in historical graphic works printed in the most comprehensive documentary publication of the $1^{\text {th }}$ century, the Theatrum Europaeum. In this publication, the year 1647 is one of the richest in terms of the number of engravings depicting the course of the war. In addition, the Swedish campaign of the same year left behind the most numerous and best preserved traces in the landscape of the $C z e c h$ lands. The paper focuses primarily on engravings related to war events at the locations of Cheb, Třebel and Teplá. It presents interim results of interdisciplinary research of these iconographic sources, which involves the tools of spatial analyses, digital terrain modelling and also new possibilities of airborne laser scanning data processing. The main aims of the research, which are also being implemented, are the confirmation of depicted localities and their localization; analyses of the scale and geometrical precision of displayed landscape; estimates of visibility and methods of creating the source materials for engravings; and a detailed comparison with other contemporary or current cartographic sources.
\end{abstract}

Keywords: Engraving, Cartographic analysis, GIS, Historic battlefield, Thirty Years' War

\section{Introduction}

Research of the transformed landscape of the Thirty Years' War in today's Czech Republic combines the methods of archaeology, history and art history with methods of digital cartography and geographical information systems. This research is linked to the complex archaeological and historical research of the former Třebel battlefield from the year 1647 (Matoušek 2006; Grabolle et al. 2009), which emphasized the possibilities and significance of the specific and narrative value of iconographic sources of the Thirty Years' War. Based on this experience, a special scientific research program was launched for the study of iconographic sources of the Thirty Years' War in today's Czech Republic (i.e. a total of 21 battlefield sites depicted on period engravings). The project was undertaken by the Faculty of Humanities at Charles University in Prague and the Department of Geomatics at the Faculty of Civil Engineering of the Czech Technical University in Prague. Specific research results include e.g. publications by Matoušek \& Blažková (2012) or Janata \& Zimová (2013). The archaeological segment of research, undertaken by the University of West Bohemia in Pilsen, was based on contemporary trends in historical archaeology (Majewski \& Gaimster 2011) and may be regarded as a sub-field of scientific research known at an international level as "conflict 
archaeology" and/or "battlefield archaeology" (cf. e.g. Meller [Hrsg.] 2009). One of the aims of this field is to focus on the specific impacts that military events had on local populations and the accompanying process of the abandonment of settlements.

Research of period engravings of battlefields is aimed at exploring the possible methods through which the source designs (or drawings) that subsequently formed the basis for the engravings were created. The research is focused on verification of depicted objects, scenes and their position within an historical context. If we assume, at least in a certain sense of the term, that the engraving may be considered to be a type of map, we may use cartometric methods to establish the approximate location accuracy of the source drawings for the engraving and its scale. A comparison with other historical and current cartographic and iconographic sources, using methods of digital cartography and geospatial analyses, can aid in identifying relics of military elements in the landscape (i.e. fortifications) that have remained preserved until the present date.

\section{Historical Context}

The campaign led by the Swedish Army in 1647 took place at a time when the long-awaited end of the Thirty Years' War was quickly nearing. However, the prospect of impending peace angered those in favor of prolonging the war. One of these men was the newly appointed commander of the Swedish Army in German lands, General C. G. Wrangel. At the very beginning of 1647, Wrangel marched east toward Bohemia. The reasons for this campaign can be explained by considering various elements of diplomacy, military strategy, but also interests that were wholly personal and private. The goals, however, were clear: to attempt once again to exert military influence on peace negotiations; to delay the coming agreement on a final peace accord; and, finally, to take advantage of opportunities in gaining personal wealth and ransack Bohemia (Matoušek 2006). The frame taken from the period engraving (Fig. 1) shows a map labelling the route of the Swedish campaign, a part of which was the siege on the City of Cheb (German Eger) in June and July; the battle of Trrebel (Tribel) in August; and the clash of troops near Teplá (Tepl) in August and September of 1647.

\section{Iconographic Sources}

Significant iconographic sources depicting the battlefield of the Thirty Years' War include the graphic works printed in the publication Theatrum Europaeum, an extensive documentary work of the $17^{\text {th }}$ century first printed in 1633 in Frankfurt by the publishing house of Basil native Matthäus Merian (1593-1650). This work mapped the political events of Europe primarily during the Thirty Years' War, although editions continued to be printed until 1738 , when the $21^{\text {st }}$ volume was completed. ${ }^{1}$

Additional sources from the period also include the well-known publication from Merian's publishing house, Topographia. A total of 31 volumes deal with a wide spectrum of locations around Europe and was published over the course of 46 years (1642-1648). The Czech lands were dealt with in the volume entitled Topographia Bohemiae, Moraviae et Silesiae. ${ }^{2}$

\footnotetext{
${ }^{1}$ Vol. V: urn:nbn:de:bvb:384-uba000240-0 or Vol. VI: urn:nbn:de:bvb:384-uba000241-5

${ }^{2}$ The whole title contained the German epithet das ist Beschreibung und eigentliche Abbildung der vornehmsten, und bekandtisten Stätte, und Plätze, in dem Königreich Boheim und einverleibten Ländern, Mähren, und Schlesien (urn:nbn:de:bvb:12-bsb10802301-8).
} 


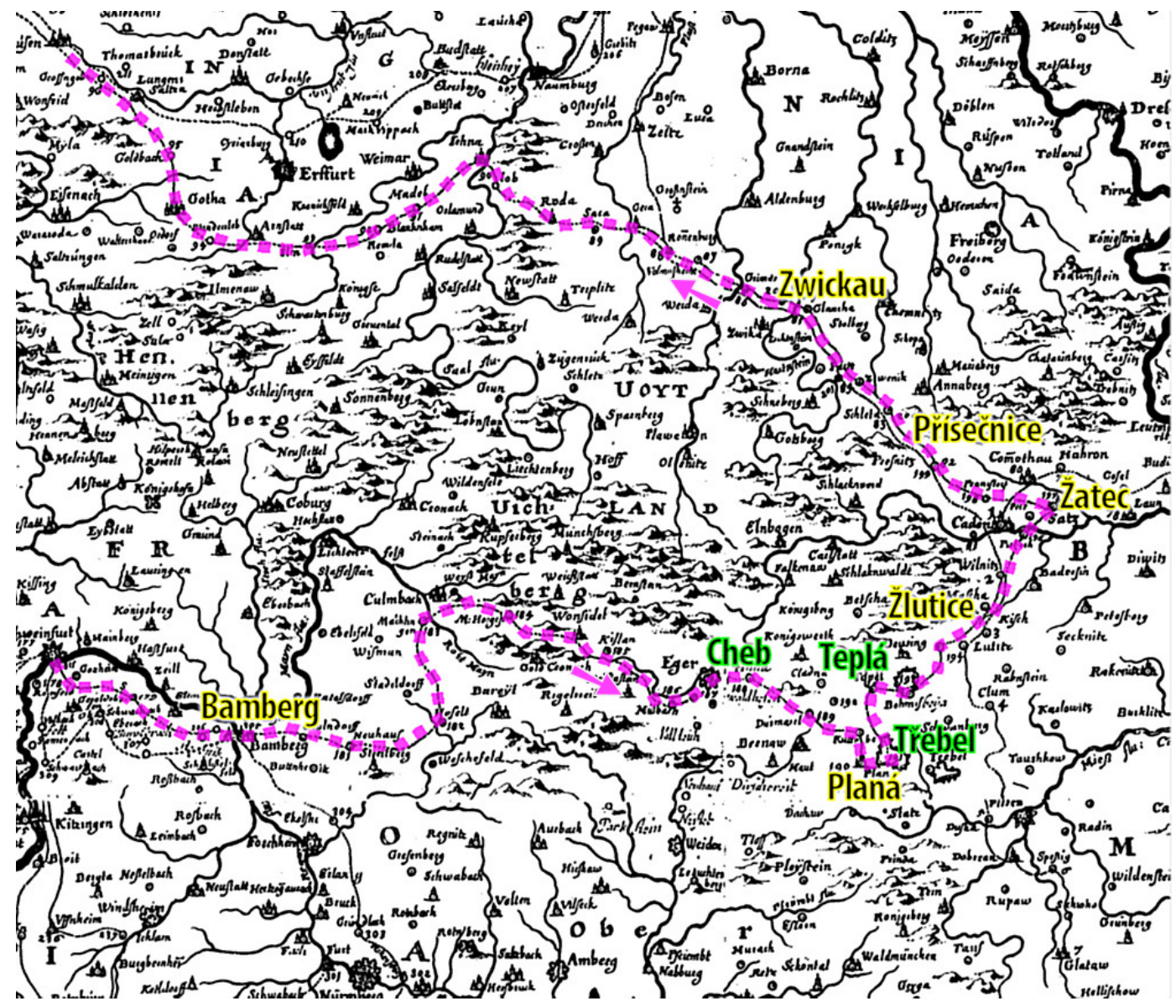

Figure 1: Swedish campaign to Bohemia in 1647. Cut-out from engraving published in Theatrum Europaeum, vol. VI (modified).

In addition to extensive descriptive chapters (written in German), these publications contain an extremely valuable illustrative apparatus. It records the prominent figures of the time, provides numerous "vedutas" of cities, and contains maps and other depictions of significant events including military battles. Engravings of a military-geographic character graphically document the period and also served as a type of propaganda. Study of available maps and sources depicting various locations of the Thirty Years' War may provide valuable information on the state and development of the landscape, settlements, and significant buildings, but also the military and tactical elements in use at the time.

The selected collection of sources on the Swedish campaign in 1647 includes two engravings of the siege of Cheb, one engraving of the battle of Třebel, and one engraving of the battle of Teplá. Prints of the engravings were published in the $17^{\text {th }}$ century in the $5^{\text {th }}$ and $6^{\text {th }}$ volume of the Theatrum Europaeum mostly under anonymous authors. Dimensions of these engravings measure from 345 to $389 \mathrm{~mm}$ in width and 270 to $304 \mathrm{~mm}$ in height.

The project of the systematic multi-disciplinary study of iconographic sources primarily used raster images of the engravings created by the specialized workplaces of libraries, archives and other institutions (e.g. the University Library in Augsburg, the Prague City Archives, 

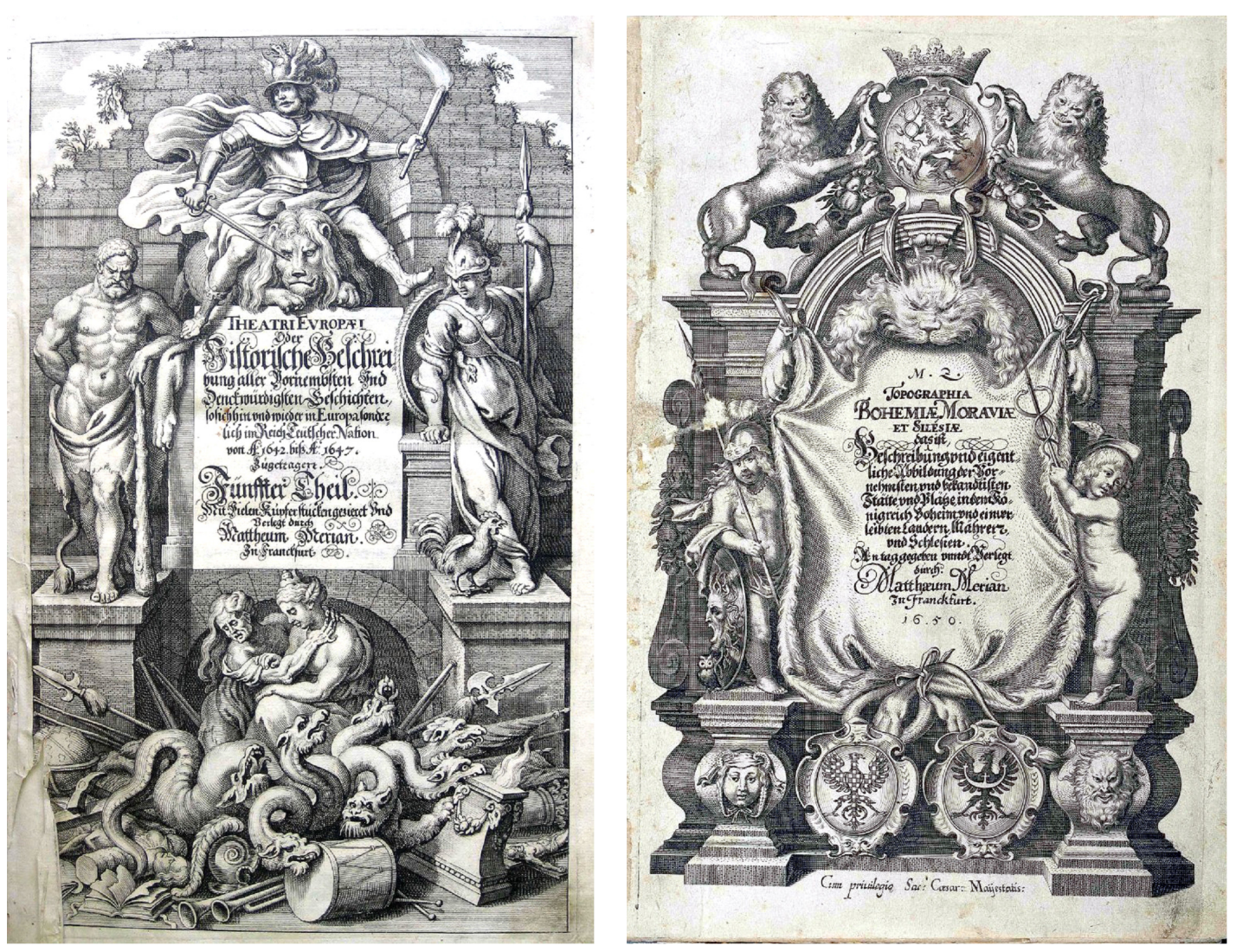

Figure 2: Front pages of Theatrum Europaeum (left) and Topographia Bohemiae, Moraviae et Silesiae publications

etc.) or copies made photographically in research rooms.

\section{Methods and Techniques}

The project team has subjected these iconographic sources to detailed scrutiny. Confirmation of the identification of depicted sites and their localization; analysis of the scale and geometric accuracy of the depicted landscape; determining levels of visibility from elevations in the terrain; and estimates of the methods through which the source drawings for the engravings were created all contributed to the complex interdisciplinary study of early modern historical events and their corresponding transformations in the landscape with the help of results of archaeological and historical research. We have also tested geophysical methods that allowed for further identification of sites and phenomena that surpass the capabilities of terrain reconnaissance, calculations or modelling. The scheme of methods and strategies for their use during research of battlefield engravings is shown in Fig. 5.

In order to compare the engraved depictions with cartographic sources, we have mainly used historical military topographic mapping, although the first military mapping ${ }^{3}$ of this kind took place under the Habsburg Monarchy at a scale of $1: 28,800$ in the Czech lands in the

\footnotetext{
${ }^{3}$ First and second military mapping here refer to "Josephian" and "Franciscan" cadastre maps commissioned by the Habsburg Monarchy and Austro-Hungarian Empire respectively.
} 


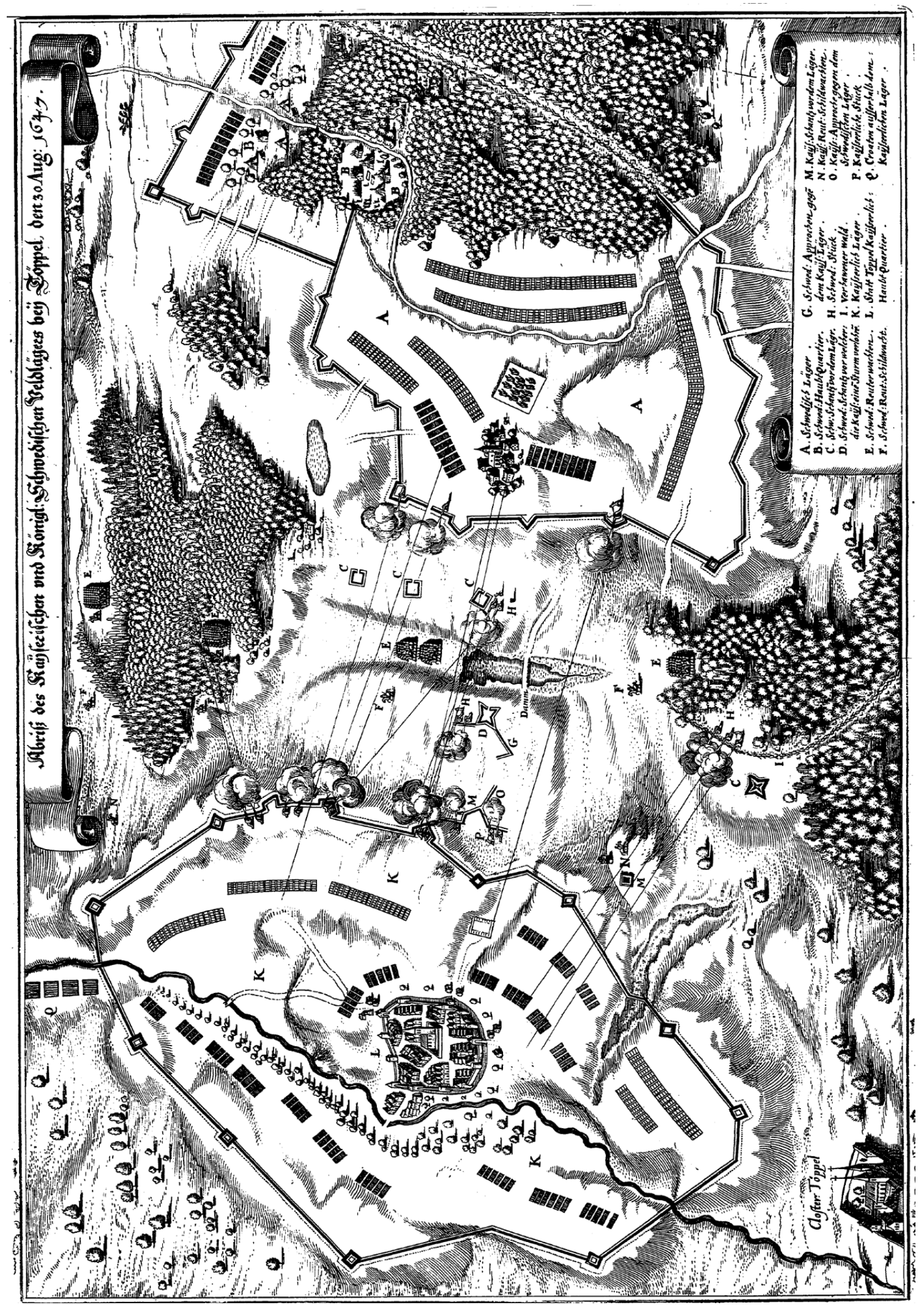

Figure 3: Illustration of the whole engraving (the siege of Cheb/Eger). 

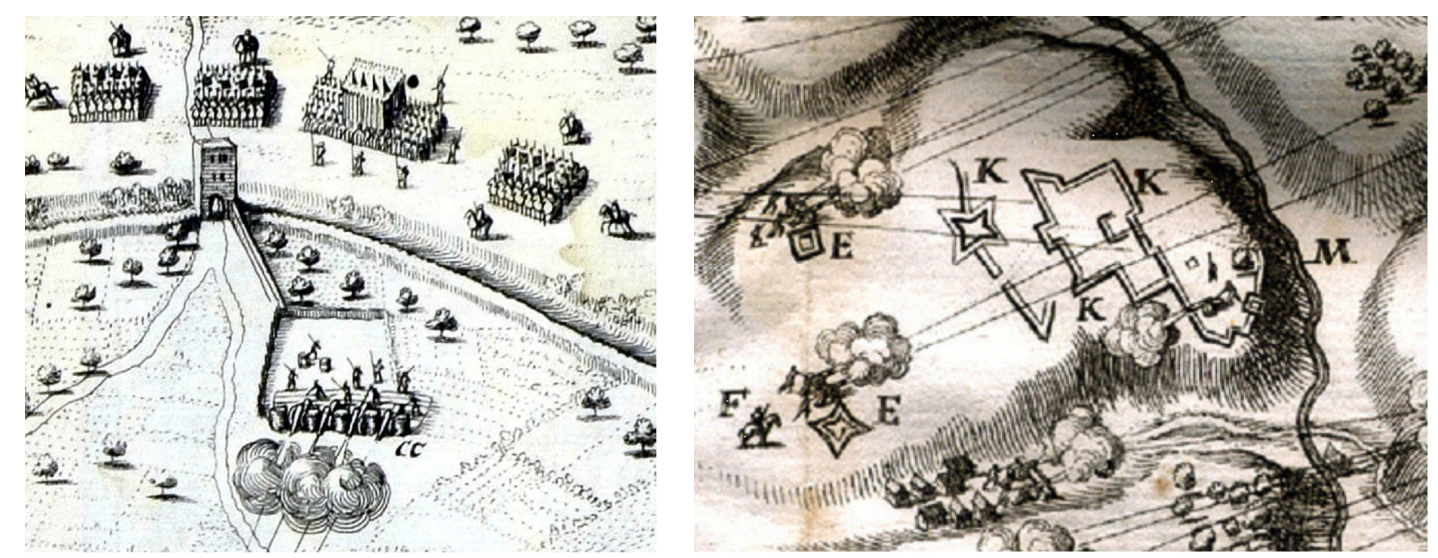

Figure 4: Cut-outs showing detail of military contents depiction.

second half of the $18^{\text {th }}$ century. In order to identify elements on the engraving, maps from the Austrian Empire's Stable Cadastre from the first half of the $19^{\text {th }}$ century may also be used, including preserved maps of settlements. Cartographic sources from the era preceding "Josephian" mapping are not sufficiently detailed and often lack the mathematical and geometric framework necessary for linking them to the depictions contained in the engravings.

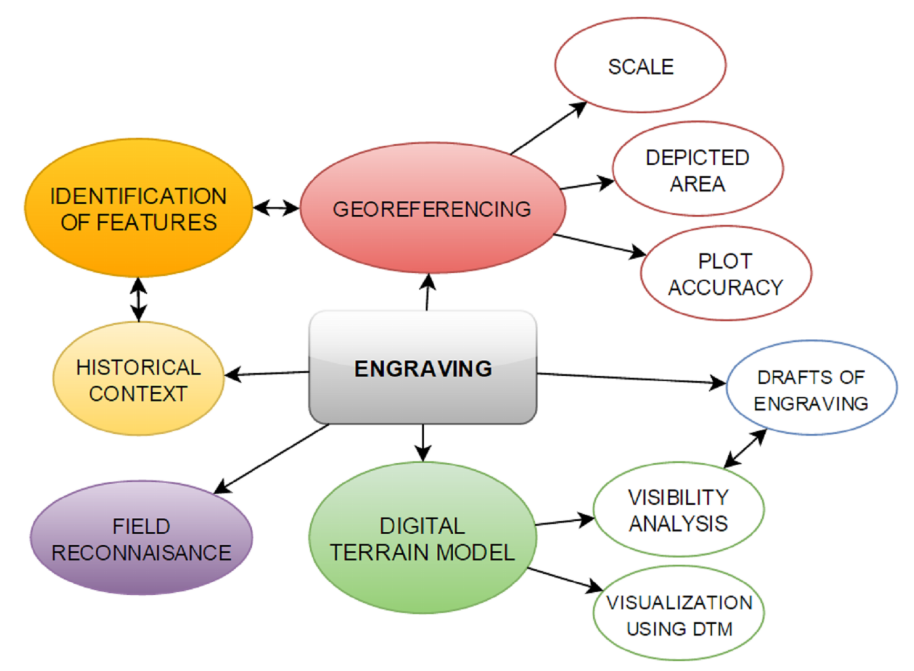

Figure 5: Research methods and their relations.

Contemporary maps and the data contained in them are for the most part useless due to the large offset of time. They show landscape and settlement changes brought on by industrialization, the construction of roads, regulation of water courses, the decline of historical fortification systems of cities that gave way to new construction, collectivization in agriculture, land consolidation and so forth. They can, however, serve to define the territory depicted on the engravings in terms of today's landscape.

The digital model of the topography of depicted locations was created via DMR 5G data gathered by airborne laser scanning (ALS) technology. The data is provided until approximately 2013 with a standard deviation of up to $18 \mathrm{~cm}$ in the coordinate position; in height, 
the deviation is up to $18 \mathrm{~cm}$ in the exposed ground and up to $40 \mathrm{~cm}$ in the ground covered by vegetation. The density of scanning is roughly 5 points per square metre, while in the areas covered by dense vegetation it may drop to a value of 1 to 2 points per square metre. ${ }^{4}$

For spatial data processing, ArcGIS and MapAnalyst software was used. The evaluation of ALS data was handled in Envi LiDAR and Terrascan software.

\section{Results of GIS Data Processing}

Each of the engravings is original in its own way; however, we can identify certain traits that are shared to at least a certain degree by all the engravings. By doing so, we can also adapt the research methodology to various details of the selected sources where needed.

\section{Identification of Features in Engravings}

In order to identify the various elements of an engraving, the engraving must first be put into historical context. To do so, descriptions linked to the image of the situation (e.g. legends, accompanying depictions, etc.) can be used. More importantly, documentary publications from the period can be used, which often describe the course of battles in sufficient detail. Elements of the image such as various settlements or their individual buildings, bodies of water or networks of roads can all be used to georeference the engraving in relation to other cartographic sources, which is crucial for further
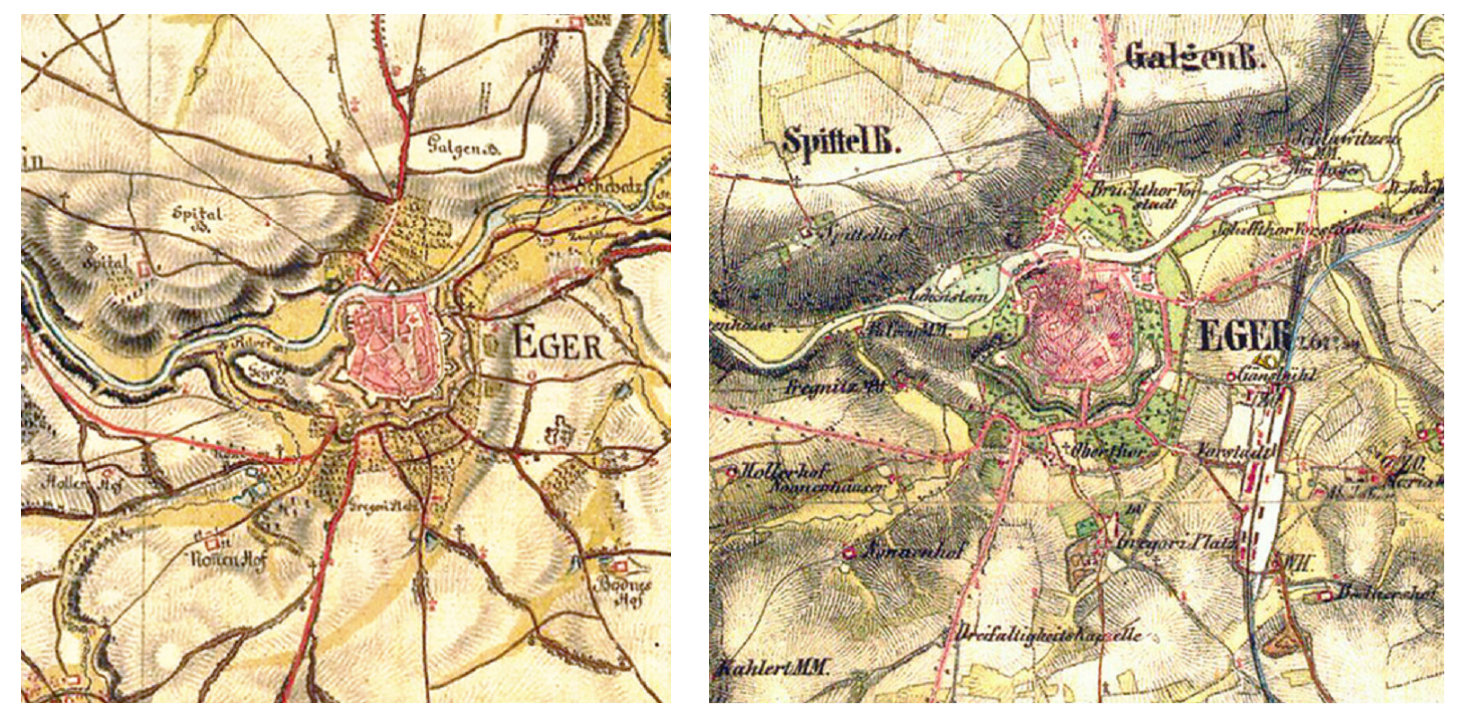

Figure 6: Cheb (Eger) in $1^{\text {st }}$ and $2^{\text {nd }}$ Military Mapping.

\section{Georeferencing}

Maps of first and second military mapping are the most common basis for georeferencing. There is an advantage in using the latter type due to the fact that mapping took place with the help of established astronomical-geodetic networks and thus had a relatively high degree of accuracy (nominal deviations in position due to the transformation of individual map pages

\footnotetext{
${ }^{4}$ more to quality and properties of the data in (Šíma 2013)
} 
Table 1: Results of transformation of particular sources.

\begin{tabular}{|c|c|c|c|}
\hline \multirow{2}{*}{} & \multicolumn{3}{|c|}{ Standard deviation of transformation [m] } \\
\cline { 2 - 4 } & $1^{\text {st }}$ milit. map. & $2^{\text {nd }}$ milit. map. & engraving \\
\hline \hline Cheb & 168 & 11 & 169 \\
\hline Třebel & 87 & 7 & 295 \\
\hline Teplá & 203 & 12 & 97 \\
\hline \hline
\end{tabular}

is in the tens of metres at a maximum). With the help of sophisticated methods of adjustment of the first military survey maps (Cajthaml 2013), this map series may also be used. They are less accurate, but are historically closer to the era of the Thirty Years' War.

In terms of control points for the geometric transformation ${ }^{5}$ of the engraving, preference is given to elements of topographic content - e.g. settlements, individual buildings, road networks, or surfaces and bodies of water, in accordance with Cajthaml's (2012) findings. Lesser-used points also include vegetation cover or terrain morphology. In the event that relics of a military character are still preserved at present or are depicted on older maps (redutes, ramparts, gallows, etc.), they may also be used for georeferencing.

\section{Depicted Reality and Visibility Analyses}

The digital model of the terrain serves to reconstruct height conditions of the depicted landscape and to identify the points from which the authors of the engravings may have created their source drawings. It is unfortunate that no reliable hypsography information exists from the time, which would help reconstruct the landscape to its original state during the $17^{\text {th }}$ century. In the case of forested sites with village settlements (e.g. engravings of Teplá and Třebel), changes in hypsographic conditions are likely to have been small. In towns and their surrounding areas, however, extensive transformations took place over the period of almost four centuries due to industrialization in the $19^{\text {th }}$ century and the expansion of the building of houses and road networks in the $20^{\text {th }}$ century. In older maps, these changes are recorded only planimetrically. Thus, the shape of topography during the $17^{\text {th }}$ century and the state of development or forestation of sites (which also has a significant impact on visibility modelling) can only be inferred implicitly.

Therefore, judging from the way situations are depicted in the engravings, we can likely infer that the military engineers created a sketch at first, on which the work of engravers in the publishing house was later based on when preparing the final engraving. The sites from which the sketches were created were elevated areas near the towns or battlefields or were other high structures (e.g. towers). With the help of terrain models, we can verify the possibilities of visibility from individual elevated standpoints, as shown in Fig. 7. There, purple areas represent those visible from at least one of four observation points around the town.

If the author of the engraving and his affiliation to a warring party is known, we can infer which portion of the battlefield this observer could have been located in and, on the other hand, what parts of the landscape the author had only more superficial knowledge of. In many

\footnotetext{
${ }^{5}$ usually, standard affine or polynomial transformations are used, but network transformation per partes with sufficient amount of control points or robust adjustment can be used with advantage
} 


\section{T. Janata and R. Zimová: Using GIS AND methods of Digital CARTography}

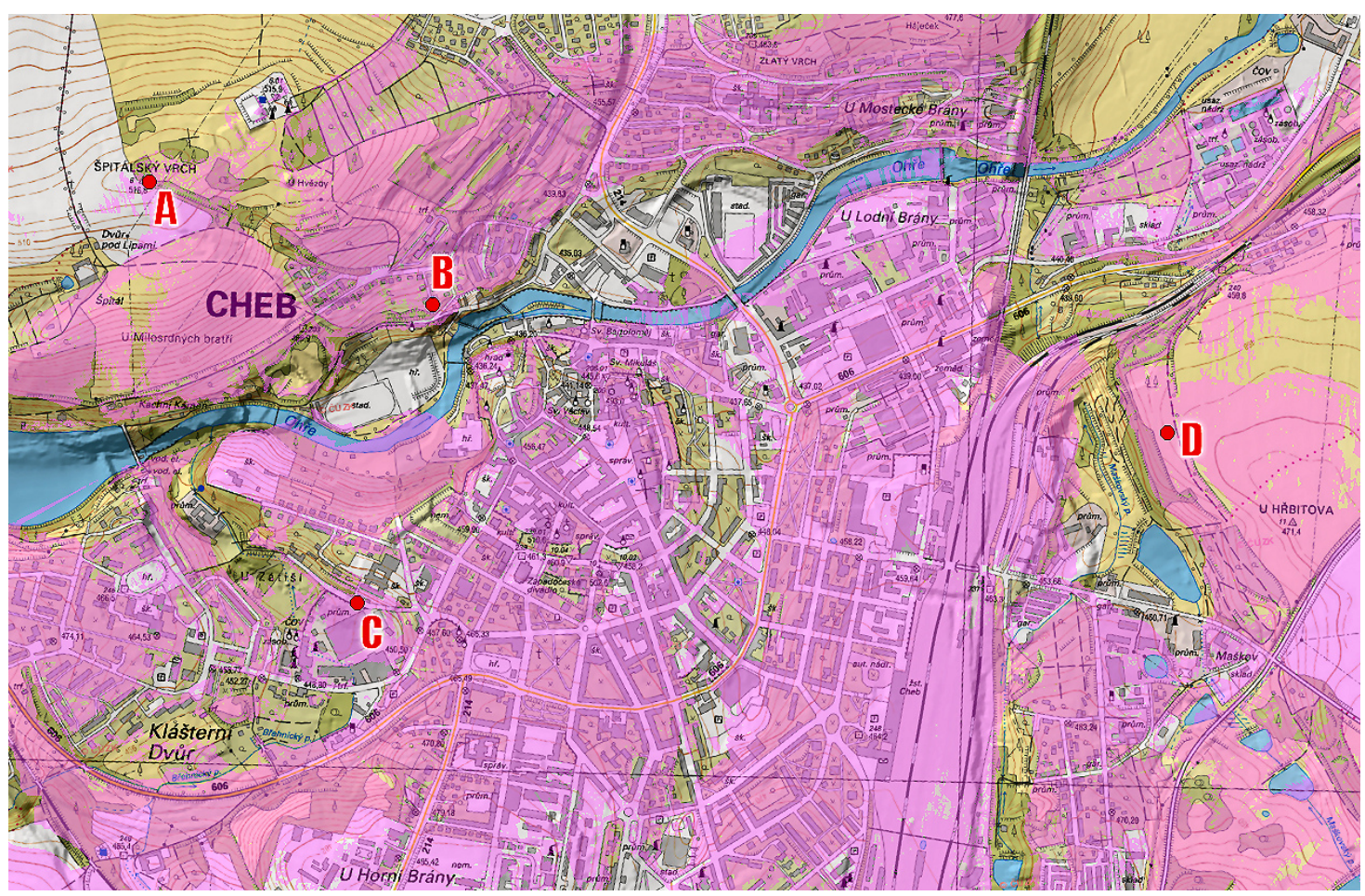

Figure 7: Visibility analysis from estimated observation localities (Cheb/Eger engraving). Background: Base map of the Czech Republic 1 : 10 thousand supplemented by shaded relief derived from LiDAR data.

engravings, it has been proven that various sections of the landscape had been fabricated due to either inaccessibility or simply for a more dramatic effect of the scene and to fill in the frame of the engraving (depicted territory is always in the shape of an irregular polygon).

It is possible that the creators in some situations were in possession of older engravings, maps and other similar sources that could have provided the framework for the depicted situation. Towns and their plans on the engravings often show a higher degree of accuracy than the rest of the drawn territory. However, no known sources in the form of sketches or other models of the engravings have been preserved in Czech lands. During the process of creating drawings of fortifications and settlements, simple methods of measurement could have been applied. The engraving could have served not only as a documentary image of the battle scene, but also as a plan of the construction of fortification systems and a model for tactical planning.

\section{Analysis of Scale of the Drawing}

While determining the scale of the engraving, we encounter the absence of a basis for the drawing. The set scale is thus only approximate - this is due to a commonly low number of control points found (around ten) and the fact that they are located in somewhat inopportune places (mostly at the center of the engraving).

The scale may be determined using several methods:

- by establishing an approximate scale for various directions (two are sufficient in practice), 


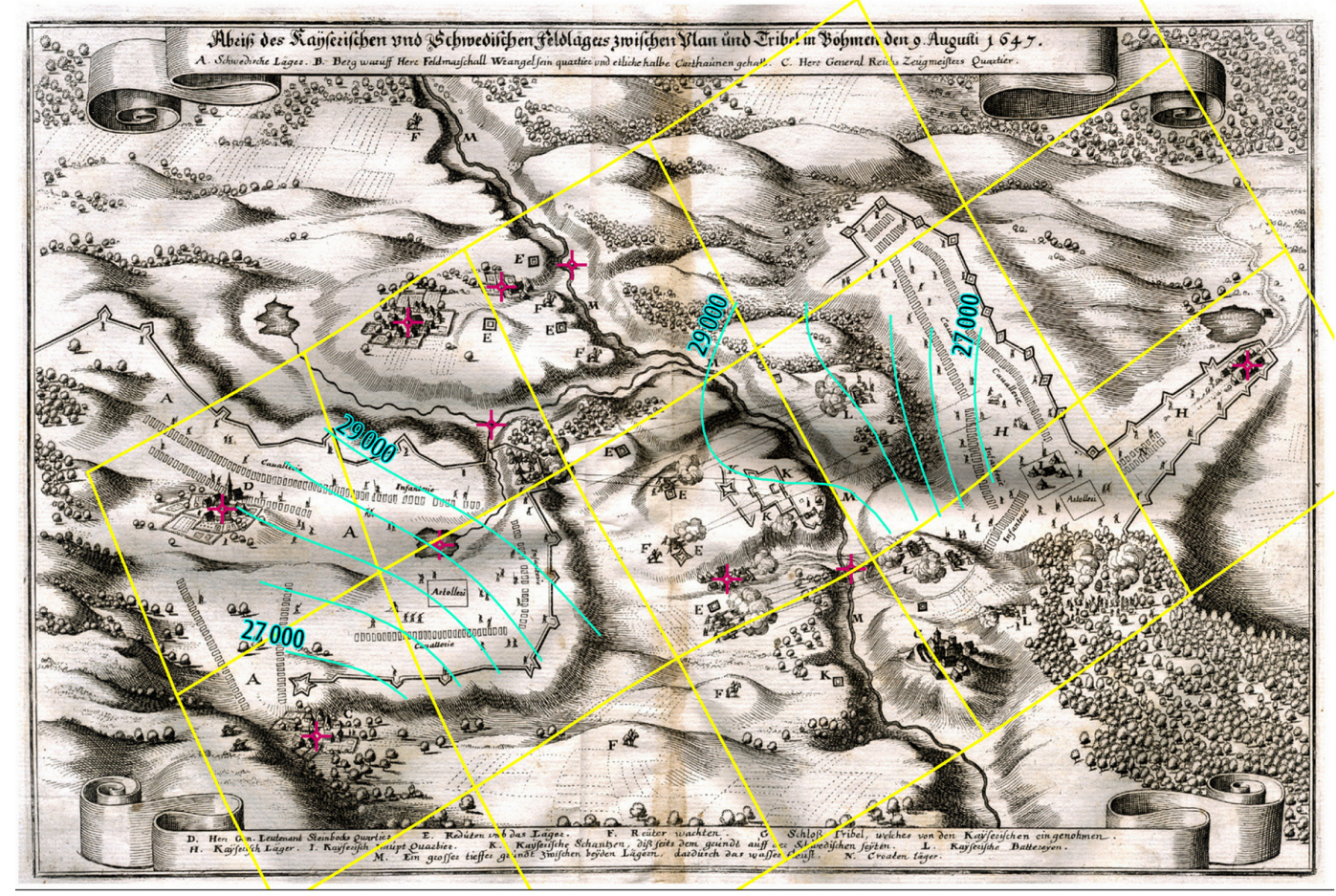

Figure 8: Isolines of scale number (cyan) and indication of 2-kilometre grid deformation.

most conveniently in the direction of the perspective drawing and in the direction perpendicular to it;

- by establishing one average value for the whole image for very rough purposes or in the case that the scale in various parts of the image does not change much or there is an insufficient amount of points;

- in the event of insufficient scalable points, by creating a map of contour lines of the scale number that properly shows the character of changes in scale and thus the accuracy of the drawn elements in individual sections of the engraving. The spline method or robust transformation method can be used, thus eliminating the influence of gross errors in control points.

The image of the battlefield landscapes on the engravings primarily shows a medium scale ranging from $1: 8,000$ to $1: 25,000$. Fig. 8 shows analysis results of the scale in the engraving of the battle of Tŕebel. The depicted contour lines of the scale number show only a relatively weak deformation in space, i.e. the accuracy of the depicted territory is relatively high. Contrary to this, the engravings depicting sieges on towns show a higher accuracy in areas of the town than in the rest of the drawing's area.

\section{Identification of Terrain Relics}

This section deals primarily with the engraving of the battles under Třebel Castle, in which a significant amount of relics have been recovered thanks to the character of the landscape and the number of completed fortification activities on the former battlefield (Matoušek 2006). 
Relics of fortifications can be found almost exclusively in areas that were bare during the Thirty Years' War and were quickly overgrown with vegetation after it, as vegetation often conserves these areas. In terms of fields and meadows, relics of fortifications have long since been ploughed up, collected by farming peasants, or were destroyed in other ways.

Remains of the terrain found in the landscape can later serve as new identification points and clarify the original georeferencing. In the case of the battle under Třebel Castle, a total of seven sites were identified and confirmed by field work. These sites then accompanied the eleven original sites used for the initial transformation.
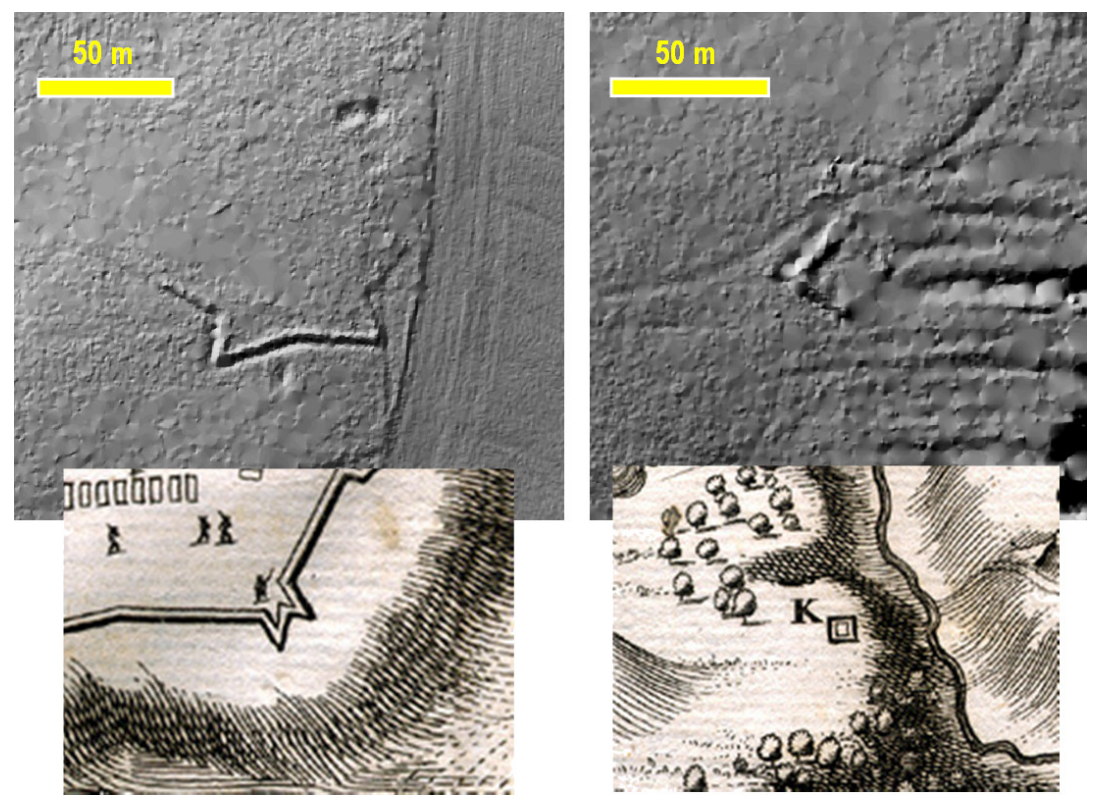

Figure 9: Comparison of identified terrain objects and their rendition in the engraving.

\section{Discussion and Conclusion}

Progressing methods of digitalization and access to archival documents, including iconographic sources, antiquated maps or publications, allow us to apply new approaches to these engravings with the help of geographical information system technology. They make the use of data contained in these engravings easier via spatial analyses.

The project is highly original in terms of Central European studies as it takes an interdisciplinary approach that aims to combine written, cartographic, archaeological, iconographic and environmental sources with systematic co-operation within a broad spectrum of research fields.

Although we were not able to prove all the general methods used to create the engravings, several of them clearly show that various sketches were made first in the publishing house, the consequences of which can be seen in the accuracy of the images as a whole. Research proved that the topological and geometrical accuracy of the main elements on the engravings such as military sites, towns, etc., was relatively exact. Therefore, engravings may also serve as an aid in searching for the remains of former battles in the landscape. Thus, simple methods of measurement or other formerly existing documents may have been used while creating 
the sketches of fortifications and settlements. The resulting engraving, however, was not necessarily just a documentary image - it may have also been a certain type of building plan or a model for waging battle in a certain location.

As far as the final research project is concerned, results were partial. We will continue to work with additional comparative locations. Testing geophysical methods, which may involve measuring using georadar or magnetometer as well as sondage using paleobotany and other non-destructive methods, could also yield new types of results. In terms of future directions of the research, the area of focus could be extended to the whole area of Central Europe, which formed the ground of the main theatre throughout the course of the Thirty Years' War. In addition to locations in the Czech Republic, narrative documentary publications from the $17^{\text {th }}$ century contain dozens of other engravings from the territory of today's Poland, Germany, Slovakia, Austria and various other countries that have yet to be analyzed from a historicalcartographic point of view.

\section{Acknowledgements}

This paper was financially supported by the Grant Agency of the Czech Republic, grant No. $15-03380$ S.

\section{References}

[1] Douglas V. Armstrong and Mark W. Hauser. "A Sea of Diversity: Historical Archaeology in the Caribbean". In: International Handbook of Historical Archaeology. Ed. by David Gaimster and Teresita Majewski. New York, NY: Springer New York, 2009, pp. 583612. ISBN: 978-0-387-72071-5. DOI: 10.1007/978-0-387-72071-5_32.

[2] Jiří Cajthaml. Analysis of old maps in digital environment on thew example of Müller's map of Bohemia and Moravia. (in Czech). Praha, Czech Republic: Česká technika, 2012. ISBN: 978-80-01-05010-1.

[3] Jiří Cajthaml. "Polynomial georeferencing method for old map series". In: 13th International Multidisciplinary Scientific Geoconference SGEM 2013 Proceedings. Vol. I. Sofia, Bulgaria: STEF92 Technology Ltd, 2013, pp. 859-866. ISBN: 978-954-91818-9-0.

[4] Roman Grabolle et al. "Die Schlacht bei Třebel/Triebl im Jahr 1647 und weitere Untersuchungen zur Archäologie des Krieges in der Tschechischen Republik". In: Schlachtfeldarchäologie = Battlefield archaeology : 1. Mitteldeutscher Archäologentag vom 09. bis 11. Oktober 2008 in Halle (Saale) / Harald Meller (hrsg.) (2009), pp. 173-186. ISSN: 18674402.

[5] Tomáš Janata and Růžena Zimová. "The Historical-Cartographic Research on Battlefields of the Thirty Years' War: The Engraving of the Siege of Pilsen in 1618". In: 13th International Multidisciplinary Scientific Geoconference SGEM 2013 Proceedings. Vol. I. Sofia, Bulgaria: STEF92 Technology Ltd., 2013, pp. 967-974. ISBN: 978-954-91818-9-0.

[6] Václav Matoušek. Třebel. Obraz krajiny s bitvou. (in Czech). Praha: Academia, 2006. 
[7] Václav Matoušek and Tereza Blažková. "The image and reality of battlefields from the Thirty Years' War. A preliminary report on a project for the systematic study of engravings of the battlefields from the Thirty Years' War in the territory of the Czech Republic". In: Studies in Post-Medieval Archaeology 4. Praha: Archaia, 2012, pp. 269288.

[8] Jiří Š́ma. "Quality parameters of digital aerial survey and airborne laser scanning covering the entire area of the Czech Republic". In: Geoinformatics FCE CTU 10 (Nov. 2013), pp. 15-26. DOI: 10.14311/gi.10.2. 